\title{
The Role of MUC16 Mucin (CA125) in the Pathogenesis of Ovarian Cancer
}

\author{
Claudine Rancourt, Isabelle Matte, Denis Lane and Alain Piché* \\ Département de Microbiologie et Infectiologie \\ Faculté de Médecine, Université de Sherbrooke \\ Canada
}

\section{Introduction}

The majority of epithelial ovarian carcinomas (EOCs) are derived from the ovarian surface epithelium (OSE). EOCs are the most lethal of all gynecological malignancies. Most patients present with advanced diseases in which tumor cells are disseminated throughout the peritoneal cavity. MUC16 serum level is a well-established marker for ovarian cancer (OC) progression and disease response to treatment. MUC16 is a high molecular weight, membrane associated-mucin, which is aberrantly expressed in advanced serous EOC. MUC16 is also expressed at the surface of corneal and respiratory epithelial cells, and the surface of female reproductive tract epithelium. It is however not expressed by the normal OSE. Like other membrane-bounded mucins, this glycosylated protein is primarily involved in the lubrification of epithelial luminal surfaces. MUC16 glycoprotein possesses unique structural motifs as compared with other membrane-bounded mucins. Its ectodomain is composed of a large heavily O-glycosylated N-terminus and a tandem repeat region with over 60 tandem repeats. MUC16 C-terminal domain (CTD) is composed of an extracellular unique region which contains a potential proteolytic cleavage site, a transmembrane domain and a short cytoplasmic tail with possible phosphorylation sites. MUC16 domains most likely have various functions resulting in activation of signalling pathways which regulate different tumor cell phenotypes. Indeed, recent functional studies have begun to uncover the unique role of MUC16 in the pathogenesis of OC. The present review will discuss the unique structure and functional roles of MUC16 in OC.

\section{Ovarian cancer overview}

OC is the fifth cause of cancer-related death in women in North America, the second most common gynecological cancer, and the leading cause of death from gynecological malignancies (Ozols et al, 2004). One in 78 women will develop OC during her lifetime (Jemal et al., 2010). In 2010, nearly 22,000 new cases were estimated to occur in the United States and approximately 14,000 women are expected to die from this disease (Jemal et al., 2010). Similar incidence and mortality has been observed in Canada, relative to the total population. Although survival rates approach $90 \%$ in OC patients diagnosed at early stage, most patients

${ }^{*}$ Corresponding Author 
$(\sim 80 \%)$ are diagnosed with advanced diseases and metastases throughout the peritoneal cavity (Bast et al., 2009). For these women, the 5-year survival rate is less than $30 \%$.

Although OC may arise from all cell types composing the ovaries, EOC arising from the single-cell layer coelomic epithelium surrounding the ovaries, from postovulatory inclusion cysts or from the fimbriated end of the fallopian tube, are by far the most common $(85-90 \%$ of all OC) (Ozols et al, 2004; Auersperg et al., 2001; Landen et al., 2008; Kindelberger et al., 2007; Crum et al., 2007 (2); Dubeau 2008; Kurman et al., 2010). EOC presents substantial heterogeneity in terms of grade and histology. Most frequent EOCs divided into serous, mucinous, endometrioid and clear cell histotypes (Bast and al. 2009). Each histotype shows a distinctive gene expression and immunohistochemical profiling (Schwartz et al., 2002; Ouellet et al., 2005; Ouellet et al., 2006; Ouellet et al., 2008), and differs in the response to therapy (Bast et al., 2009). Despite evidence of considerable heterogeneity in their histological phenotypes and molecular profiling (Bast et al., 2009; Konstantinopoulos et al., 2008; Soslow 2008), most cases of EOC are treated in a similar fashion.

Early detection of cancer patient remains an important objective in the field because over $70 \%$ of patients with EOC are diagnosed at late stage disease, with dissemination of tumor implants throughout the peritoneal cavity (Ozols et al, 2004; Aletti et al., 2007; Goff et al., 2000). Only $10-15 \%$ of these patients maintain a complete response after the initial therapy. The mean survival of patients that present with late stage disease, which is the case for most patients, is 39 months (Herzog 2004). Recurrence is associated with incurable diseases in most cases. The main obstacle to an effective treatment is the failure of the initial chemotherapy to eradicate a sufficient number of tumor cells to prevent disease recurrence. In this context, deficiency in the apoptotic cascade among tumor cells is a key hallmark of EOC.

The current standard treatment for advanced EOC consists of cytoreductive surgery and chemotherapy. Paclitaxel combined with platinum-based regimen is the standard first-line chemotherapy used for all patients with EOC (Colombo et al., 2006). Serous EOC can be considered a chemosensitive neoplasm as most $(80 \%)$ patients initially respond to the combination of paclitaxel and platinum-based drugs (McGuire et al., 1996). However, $90 \%$ of the patients that initially responded will eventually develop chemotherapy-resistant diseases (Mano et al., 2007). Although rarely curative, patients that do not respond to the first-line chemotherapy are given second-line and third-line regimens of chemotherapy in an attempt to prolong life and palliate symptoms.

Early on, MUC16 mucin has been recognized as a tumor-associated antigen because of its overexpression in EOC. Measurements of MUC16 serum level have been very useful over the years to monitor disease response or progression (Bast et al., 2005). MUC16 is overexpressed in EOC, cleaved from the cell surface and detected into the peritoneal fluid and the blood. Since the characterization of the OC125 monoclonal antibody raised against the human ovarian cancer cell line OVCA433 in 1981 (Bast et al., 1981; Bast et al., 1983), a variety of MUC16-linked antibodies have been developed including VK8, M11 and 4H11 (Dharma Rao et al., 2010; Nustad et al., 2002). Except for $4 \mathrm{H} 11$ antibody, which recognizes an epitope in the noncleaved ectodomain of MUC16, other MUC16 antibodies bind to the glycosylated portion of the molecule. Measurement of serum MUC16 tumor antigen is an important part of the clinical management for EOC patients. Elevated levels of serum MUC16 are common in patients with advanced disease of serous histotype $(\sim 90 \%)$. It decreases to $50 \%-60 \%$ in patients with early stage OC. It was shown by several 
groups that rising and falling levels of serum MUC16 correlate with progression and regression of the disease and this formed the basis for monitoring MUC16 serum levels for patient follow-up (Bast et al., 1983; Canney et al., 1984; Vergote et al., 1987). However, up to $20 \%$ of patients with advanced EOC have normal serum level of MUC16. Furthermore, MUC16 levels can be elevated in various benign diseases including menstruation, first trimester pregnancy, endometriosis, adenomyosis, salpingitis, uterine fibroids, chronic renal failure or in inflammation of the pleura, peritoneum or pericardium (Bagdwell et al., 2007; Xiaofang et al., 2007). MUC16 is therefore not specific for EOC. MUC16, as a single modality, is not currently use for screening of EOC because of its lack of sensitivity and specificity.

Despite its recognized utility for the follow up of patients with EOC over the last three decades, the understanding of MUC16 structure became apparent only with the cloning of the gene in 2001. In addition, because of the lack of suitable cellular models, MUC16 functions have remained mostly unknown until very recently.

\section{MUC16 structure}

Although MUC16 was recognized as a high molecular weight glycoprotein a few years after the description of OC125 monoclonal antibody (Davis et al., 1986), and its structure confirmed by subsequent studies (Lloyd et al., 1997; Lloyd et al., 2001), it took 20 years before the MUC16 gene could be cloned (Yin and Llyod, 2001; O'Brien et al., 2001; Yin et al., 2002). The gene is located on chromosome 19p13.2 (Yin and Lloyd, 2001). The deduced amino acid sequence of MUC16 demonstrated that it resembles other membrane-bounded mucins with high serine, threonine and proline content. With a molecular weight of $>2 \mathrm{MDa}$, MUC16 is the largest membrane-bounded mucin known to date (O'Brien et al., 2001; O'Brien et al., 2002). This glycoprotein is composed of three major domains: an N-terminal domain, a large multiple repeat domain (up to 60 tandem repeats of 156 amino acids each) and a C-terminal domain (O'Brien et al., 2001) (Fig. 1). The N-terminal domain and the repeat domain are heavily glycosylated with both $\mathrm{O}$ - and N-linked oligosaccharides (Kui et al., 2003). The Cterminal domain is composed of an extracellular domain with sea urchin sperm protein, enterokinase and agrin (SEA) domains, a transmembrane domain to anchor the protein to the cellular membrane and a short cytoplasmic tail (31 amino acids) with potential serine, threonine and tyrosine phosphorylation sites. The phosphorylation of MUC16 cytoplasmic tail has been associated with its secretion (Fendrick et al., 1997). The secretion of MUC16 is stimulated by epidermal growth factor (EGF) or tyrosine phosphatases (Konishi et al., 1994). Its shedding is decreased by glucocorticoids (Karlan et al., 1988).

Human MUC16 differs from other mucins by having 16 SEA domains located near the membrane-spanning sequence. Other membrane-bounded mucins usually have a single SEA domain (Duraisamy et al., 2006). SEA domains consist of about 120 amino acids. Sequence analysis of MUC16 SEA modules showed that they display some sequence variability. The second MUC16 SEA domain however is relatively conserved and most closely resembles the SEA domain found in other mucins. It may therefore provide the preferential cleavage site, like as in MUC1 and MUC3, which allows release of MUC16 from the cell surface. This, however, remains to be confirmed. Unlike MUC1 and MUC4, MUC16 lacks an EGF-like domain. Through their EGF-like motif located at C-terminal domain (extracellular portion), MUC1 and MUC4 bind to growth factor receptor tyrosine kinases (RTKs) such as erbB family and fibroblast growth factor receptor 3 (FGFR3) (Li et 
al., 2001; Ren et al., 2006; Schroeder et al., 2001; Pochampalli et al., 2007). The formation of heterodimer with RTKs causes cross-phosphorylation of their respective cytoplasmic domain leading to the activation of various signaling pathways (Bafna et al., 2010). Because MUC16 lacks an RTK binding motif in its C-terminal domain, it is not clear whether MUC16-induced signaling is affected by RTKs although, as mentioned above, MUC16 release from the cell is stimulated by EGF. Consistent with the lack of an RTK binding motif, the intracellular interaction between MUC16 and $\beta$-catenin is not affected by EGF (Comamala et al., 2011). MUC16 cytoplasmic tail contains a polybasic sequence of amino acids (RRRKK) which is predicted to bind to the ezrin/radixin/moesin (ERM) family of proteins (Fig. 2). This motif is not found in MUC1 and MUC4. The ERM proteins can interact with numerous membrane-associated proteins and the actin cytoskeleton. Consistently, MUC16 has recently been shown to interact with E-cadherin and $\beta$-catenin, and causes alteration in the actin cytoskeleton (Comamala et al., 2011). However, it remains unclear whether MUC16/ $\beta$-catenin and MUC16/E-cadherin interaction is mediated through the ERM motif of the MUC16 cytoplasmic tail. MUC1 cytoplasmic tail has been shown to bind to $\beta$-catenin and a serine-rich SXXXXXSSL motif in MUC1 is responsible for this interaction in vitro (Yamamoto et al., 1997; Wen et al., 2003; Huang et al., 2005). This motif is notably absent in MUC16. Interestingly however, the binding of MUC1 to $\beta$-catenin in cells was independent of the serine-rich motif (Huang et al., 2005). These observations suggest that MUC16 interaction with $\beta$-catenin is mediated by an indirect mechanism, probably through another protein. The positively charged R-K rich region of MUC16 cytoplasmic tail also constitutes a putative nuclear localization motif (Bafna et al., 2010). Whether MUC16 cytoplasmic tail does indeed localize to the nucleus, as MUC1 cytoplasmic tail does (Wen et al., 2003), remains to be determined. MUC1 nuclear localization suggests that it is cleaved and released from the membrane and traffic from the membrane to the cytoplasm and the nucleus.

Although MUC16 shares some structural similarities with other membrane-bounded mucins, it possesses many unique features suggesting that its signaling capabilities and functions may differ from other mucins.

\section{Expression of MUC16 in normal tissues and ovarian tumors}

Mucins are normally expressed by epithelial cells where they play a protective role. The extensive glycosylation of mucins provides a hydrophilic environment ideal for hydration and lubrication of epithelia. MUC16 is expressed at low levels in the normal airway epithelium but levels can increase in some chronic conditions such as cystic fibrosis (Hattrup et al., 2008; Davies et al., 2007; Gronowitz et al., 2003). MUC16 is expressed at the apical surface of the ocular and conjonctival epithelium where it is part of the glycocalyx protecting corneal cells from bacterial infections and dryness (Argueso et al., 2003; Blalock et al., 2007). MUC16 is also found in lacrimal glands (Jäger et al., 2007). Immunohistochemistry of human tissues using the OC125 antibody detected MUC16 expression in other epithelia such as the fetal coelomic epithelia and its derivatives such as Müllerian duct, fallopian tube, endometrium, and endocervix. MUC16 is also expressed by mesothelial cells of the peritoneum, pleura and pericardium (Kabawat et al., 1983; Nap 1998). However, using OC125 or $4 \mathrm{H} 11$ antibodies, MUC16 expression is not found in normal adult colon, rectum, cervix, small intestine, liver, pancreatic ducts, spleen, kidney, skin and ovaries (Rao et al., 2010). 


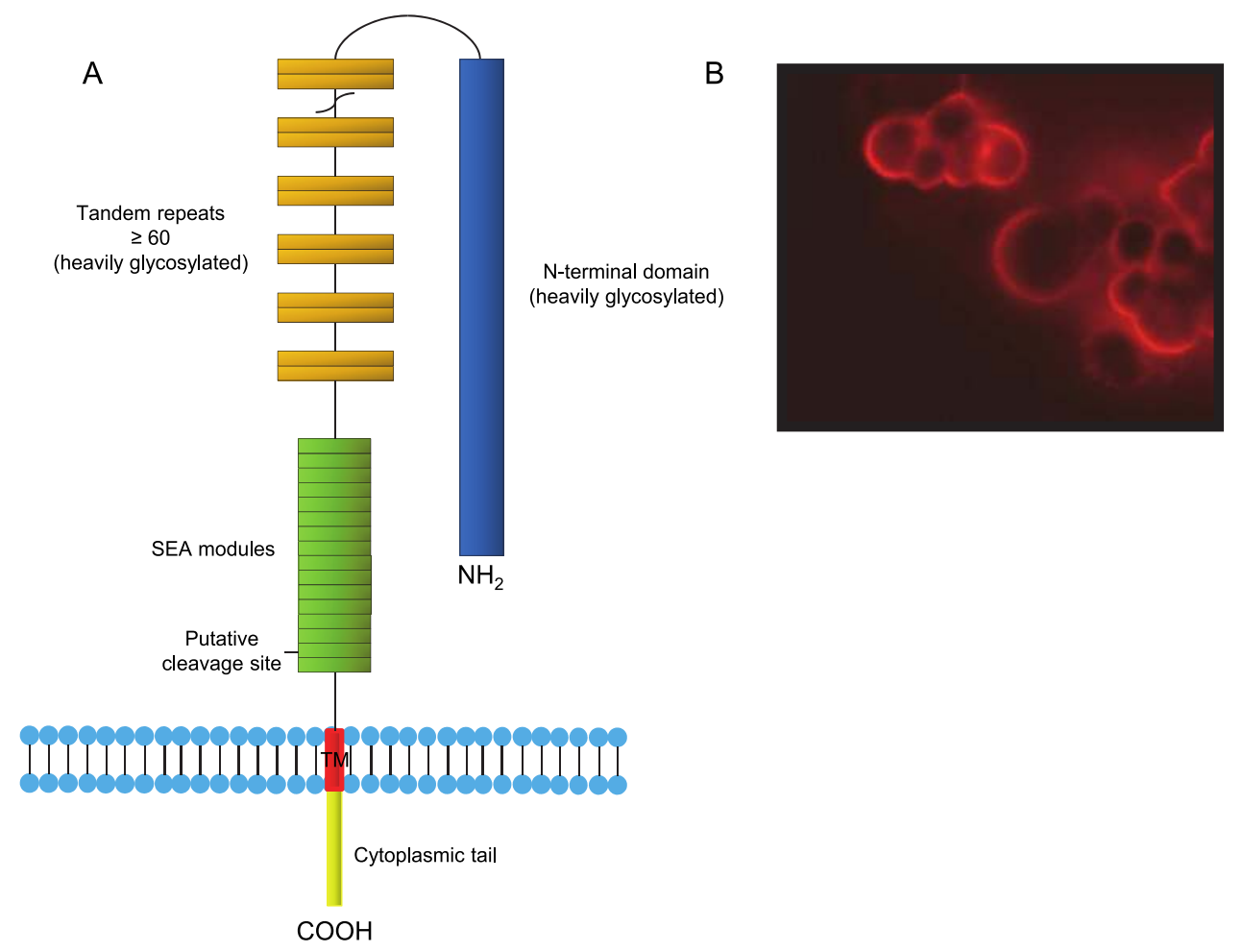

Fig. 1. Schematic structure of MUC16 mucin. A. The major domains of MUC16 include the $\mathrm{N}$-terminal domain, the tandem repeat domain and the C-terminal domain. The SEA modules contain a putative proteolytic cleavage site which divides MUC16 in two subunits. The extracellular larger subunit consists of the N-terminal (> 12,000 a.a.) and tandem repeat domains (156 a.a. each), and are heavily glycosylated. The smaller subunit contains SEA domains, a transmembrane domain (TM) and the cytoplasmic tail (31 a.a.). B. MUC16 is usually expressed at the apical surface of normal epithelial cells. In EOC cells, this pattern of expression is lost and MUC16 is expressed through the entire surface of the tumor cells. The micrograph represents OVCAR3 cells probed with M11 antibody. 


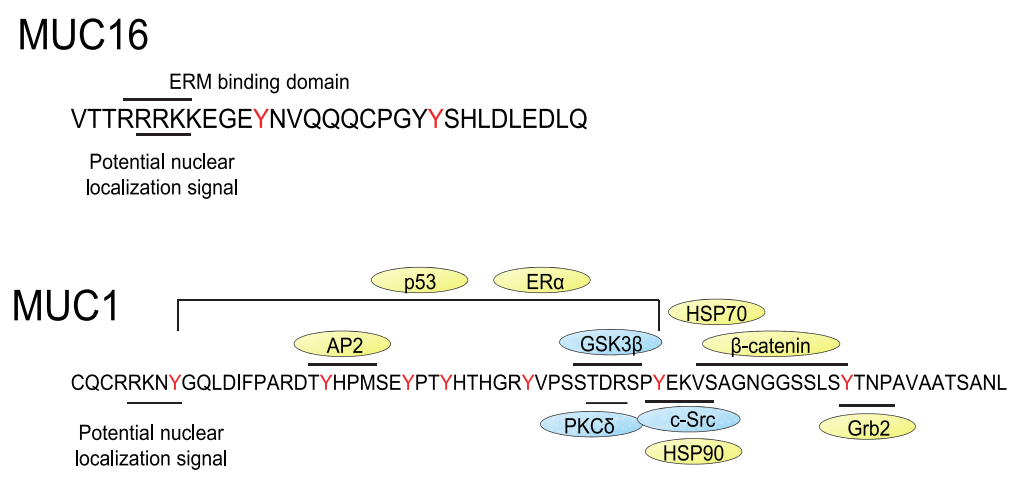

\section{MUC4}

LRFWGCSGARFSYFLNSAEALP

Fig. 2. Sequence of MUC1, MUC4 and MUC16 cytoplasmic tails. The intracellular sequence of the different mucins is shown along with protein interaction sites. MUC1 is the best characterized mucin. MUC1 cytoplasmic tail interacts with c-Src, GSK3 $\beta$, PCKס, $\beta$-catenin, p53, ERa, HSP70/90, Grb2, AP-2. Proteins with kinase activity are in blue whereas those without kinase activity are in yellow. HSP70 binds to MUC1 cytoplasmic tail in the same region as $\beta$-catenin. HSP90 binding to MUC1 depends on c-Src-induced Y-46 phosphorylation. MUC16 cytoplasmic tail has an ERM motif for potential interaction with the cytoskeleton. Both MUC1 and MUC16 contain a potential nuclear localization signal motif. MUC4 has no known interaction binding partners.

The expression of MUC16 in EOC tissues varies according to the histotype. Using tissues arrays, Hogdall et al., reported that MUC16 was expressed by $85 \%$ of serous, $65 \%$ of endometrioid, $40 \%$ of clear cell and $36 \%$ of undifferentiated adenocarcinomas, but by only $12 \%$ of mucinous cancers (Hogdall et al., 2007). Limited expression of MUC16 in mucinous EOC has also been reported by other groups (de la Cuesta et al., 1999). These authors also showed that MUC16 tissues expression was significantly correlated with the FIGO stage but not with the histological grade (Hogdall et al., 2007). In another study using tissues arrays, Rao et al., found that $56 \%-66 \%$ of serous high grade EOC expressed MUC16 depending on the antibody used (OC125 vs 4H11) (Rao et al., 2010). Other studies have also shown the lack MUC16 tissues expression in 15\% to $25 \%$ of serous EOC (Lu et al., 2004; Rosen et al., 2005; Breitenecker et al., 1989). MUC16 was also found to be expressed in a small percentage (3\%-4\%) of invasive breast carcinomas and $13 \%$ of lung carcinomas (Rao et al., 2010).

Because MUC16 is expressed in a limited subset of early stage OC, in other types of cancers and in a number of benign conditions, its serum level is neither a sensitive nor a specific marker to detect early diseases. However, as mentioned previously, it is a useful marker to monitor response to treatment. In patients who reached complete response after standard primary treatment, MUC16 nadir serum values were associated with a 
significantly longer progression-free survival (PFS) and overall survival (Rustin et al., 1996; Krivak et al., 2009; van Altena et al., 2010). Pretreatment MUC16 serum level is an independent predictor of PFS in patients with advanced EOC who received a standard chemotherapy regimen (Zorn et al., 2009). In contrast, high MUC16 expression in EOC tissues has inconsistently been associated with overall survival. de la Cuesta et al., found that, in a cohort of 50 EOC samples, patients with high tissue expression of MUC16 had a higher risk of death compared to patients with no expression (de la Cuesta et al., 1999). However, in a much larger cohort of 778 EOC samples, Hogdall et al., showed that latestage patients that lacked MUC16 tissue expression had a significantly poorer survival (Hogdall et al., 2007). In addition, MUC16 expression had no prognostic value in early stage EOC (Hogdall et al., 2007). Because the immunohistochemical detection of tissues MUC16 was based on antibodies that recognize glycosylated epitopes in the tandem repeats in these studies, the expression of a cleaved MUC16 lacking the N-terminal and the tandem repeats domains could not have been detected. Furthermore, the fact that we recently shown that a MUC16 construct consisting of the last C-terminal 283 amino acid was sufficient to promote tumorigenicity (Thériault et al., 2011), is not inconsistent with the observation that late-stage EOC lacking MUC16 (as assessed by immunohistochemistry) is associated with a worse prognosis.

\section{MUC16 roles in the initiation and progression of ovarian cancer}

Membrane-bounded mucins such as MUC1 and MUC4 are multifunctional molecules. Their large extracellular, heavily glycosylated domain promotes adequate hydration and lubrification of epithelia, and serve as a protective barrier with anti-adhesive properties. On the other hand, through their cytoplasmic tail, they activate various signaling pathways.

MUC16 is also seen as a multifunctional molecule with different domains involved in specific functions. Both secreted and membrane-bounded MUC16 have been shown to interact with galectin-1 (Seelenmeyer et al.,, 2002). The MUC16 C-terminal domain (last 1148 amino acids) appears to be sufficient for binding to galectin- 1 but this interaction requires Olinked oligosaccharide chains which are found in the repeats of the MUC16. The biological significance of this interaction remains unclear but the cell surface recruitment of galectin-1 has been associated with processes such as regulation of cell adhesion (Perillo et al., 1998). MUC16 facilitates cell-cell adhesion through its binding with mesothelin (Rump et al., 2004; Gubbels et al., 2006). The binding site for mesothelin on MUC16 is likely located in the 156 amino acid tandem repeats of the molecule (Gubbels et al., 2006). MUC16 binds primarily to the N-terminus of the extracellular domain of mesothelin (residues 296-359) (Kaneko et al., 2009). Mesothelin is a glycoprotein normally expressed on the mesothelial cells lining the peritoneal cavity (Chang et al., 1996), and by ovarian tumor cells and mesotheliomas (Rump et al., 2004). Mesothelin-MUC16 interaction could facilitate homotypic and heterotypic cellcell adhesion and peritoneal metastasis of ovarian tumors through the adhesion with mesothelial cells. This is consistent with our recent observation that MUC16 knockdown abolished homotypic cell-cell adhesion (Comamala et al., 2011). MUC16 knockdown also promotes EOC cell motility and invasiveness (Comamala et al., 2011). By regulating cell adhesion, cell motility and invasiveness, the extracellular portion of MUC16, through its interaction with galectin-1 and mesothelin, may thus play an important role in metastasis. 
MUC16 possesses immunosuppressive properties. Patankar et al., reported that natural killer (NK) cells incubated with soluble MUC16 exhibited a 50-70\% decrease in the lysis of tumor cells (Patankar et al., 2005). MUC16-expressing EOC cells are also protected from lysis by primary NK cells (Gubbels et al., 2010). Both soluble and membrane-bound MUC16 thus appear to be potent inhibitors of NK cells response in vitro. MUC16 downregulates CD16 expression in NK cells found in peritoneal fluids of patients with EOC (Patankar et al., 2005; Belisle et al., 2007). The secreted MUC16 binds to NK cells, B cells and monocytes via Siglec9, a receptor found on immune cells that inhibits the NK cell response (Belisle et al., 2010). The high levels of secreted MUC16 found in ascites may be one of the factors contributing to the immunosuppressive properties of ascites.

MUC1 and MUC4 mucins have been shown to promote the transformation of fibroblast cells. For example, when the C-terminal portion of MUC1 was stably transfected into 3Y1 fibroblast cells, soft agar colonies and subcutaneous tumors in nude mice were readily obtained (Li et al., 2003). The transforming potential of MUC16 has not been reported yet but limited data from our laboratory showed that stable transfection of MUC16 C-terminal portion (extracellular unique region, transmembrane domain and full-length cytoplasmic tail) into normal ovarian cells failed to immortalized these cells as well as HFL-1 human fibroblast lung cells (Thériault, unpublished data). Recently, ectopic expression of MUC-16 C-terminal domain has been shown to increase tumorigenicity of SKOV3 ovarian cancer cell line in a xenograft mouse model (Thériault et al., 2011). Deletion of the cytoplasmic tail completely abrogated this effect demonstrating that the enhanced tumorigenicity is mediated by interaction of the cytoplasmic tail with intracellular signaling molecules. Consistent with these results, single-chain antibody-mediated knockdown of cell surface MUC16 completely abrogated the formation of colonies in soft agar and subcutaneous tumors with OVCAR3 cells suggesting that MUC16 could be indeed an oncogene (Thériault et al., 2011). Although MUC1 and MUC4 affect tumor progression through the interaction of their cytoplasmic tail with various intracellular signaling molecules (for review, see Bafna et al., 2010), there is very limited data available on the signaling pathways activated by MUC16 cytoplasmic tail. Data from our laboratory suggest that the expression of anti-apoptotic proteins Bcl-2 and Bcl-XL and pro-apoptotic protein Bax is not affected by ectopic expression of MUC16 C-terminal domain (Matte et al.,, unpublished data). This observation contrasts with those of Raina et al., which showed that stable transfection of MUC1 in rat $3 Y 1$ fibroblast upregulates Bcl-XL but not Bcl-2 expression (Raina et al., 2004). Growth factors induce tyrosine phosphorylation of MUC1 cytoplasmic tail (Ren et al., 2006). This phosphorylation increases the binding of MUC1 to $\beta$-catenin and induces the translocation of MUC1 and $\beta$-catenin to the nucleus (Ren et al., 2006). The dysregulation of $\beta$-catenin signaling contributes to the transformed phenotype of various cancers (Huang et al., 2005). GSK3 $\beta$ phosphorylates $\beta$-catenin and targets it for ubiquitination and degradation (through $\beta$-Trcp, an E3 ubiquitin ligase) whereas the inhibition of GSK3 $\beta$ kinase activity results in the translocation of $\beta$-catenin from the cytosol to the nucleus where it acts as a transactivator of transcription. MUC1 increases the cytoplasmic and nuclear localization of $\beta$-catenin by inhibiting GSK3 $\beta$-mediated phosphorylation and degradation of $\beta$-catenin (Huang et al., 2005). Whether MUC16 could play a role similar to MUC1 is unknown. MUC16 cytoplasmic tail however lacks the $\beta$-catenin binding site. Nonetheless, MUC16 was shown to interact with $\beta$-catenin (Comamala et al., 2011). In addition, MUC16 knockdown induces $\beta$-catenin 
relocalization from the cell membrane to the cytoplasm (Comamala et al., 2011) and increases GKS3 $\beta$ activity (Comamala, unpublished data). It is thus possible that by regulating GKS3 $\beta$ activity, MUC16 regulates $\beta$-catenin subcellular localization/degradation. Importantly, $\beta$-catenin relocalization in MUC16 knockdown cells is associated with increase cell motility, migration and invasiveness in vitro (Comamala et al., 2011). So far, there is no evidence that MUC16 cytoplasmic tail co-localizes with $\beta$-catenin in the cytoplasm or the nucleus. How does MUC16 regulates GKS3 $\beta$ activity is also not known. GKS3 $\beta$ has been shown to bind directly to MUC1 cytoplasmic tail and phosphorylates serine in a DRSP site adjacent to that for the $\beta$-catenin interaction ( $\mathrm{Li}$ et al., 1998). This GKS3 $\beta$ target motif is not present in MUC16 cytoplasmic tail and it has not been established yet whether MUC16 binds to GKS3 $\beta$. The binding of GKS3 $\beta$ to MUC1 appears to be regulated by the phosphorylation of MUC1 by Src family members (Singh et al., 2006). MUC16 cytoplasmic tail is phosphorylated by EGFR activation and its phosphorylation promotes the release of the extracellular domain. Other consequence of this phosphorylation event has not been yet reported.

MUC1 and MUC4 have been implicated in the regulation of cell growth through their interaction with tyrosine kinase growth factor although these mucins act through different mechanisms (Bafna et al., 2010). MUC1 interacts with ErbB1 through its cytoplasmic tail and increases cell proliferation via the activation of ERK pathway (Jepson et al., 2002). MUC4 probably interacts with ErbB2 through its extracellular domain which leads to the activation of ERK and Akt pathways to promote cell growth (Carraway et al., 2007). MUC16 was also recently shown to affect the growth characteristics of ovarian cancer cells (Thériault et al., 2011). Although the OVCAR3 cell growth rate was not affected by MUC16 knockdown, knockdown cells reached a stationary growth phase in a shorter time. There was no appreciable difference in spontaneous apoptosis between the MUC16 knockdown cells and control cells. Conversely, stable expression of the C-terminal domain into MUC16 negative SKOV3 cells prolonged anchorage dependent growth before they reached the stationary phase. Deletion of the cytoplasmic tail completely abrogated the effect of the MUC16 Cterminal domain on cell growth. It is not known how MUC16 affects tumor cell growth. Stable expression of the MUC16 C-terminal domain in SKOV3 cells did not alter the expression or phosphorylation of EGFR. Although these observations do not rule out the involvement of receptor tyrosine kinase, other partners are probably required to modulate cell growth.

A recent study showed that MUC16 confers protection against genotoxic agents such as cisplatin in p53 null ovarian cancer cells (Boivin et al., 2009). Single-chain antibody-mediated downregulation of MUC16 sensitized the MUC16 overexpressing OVCAR3 cell line to cisplatin but not to taxol. Conversely, ectopic expression of MUC16 C-terminal domain increased SKOV3 cell line resistance to cisplatin. The downregulation of MUC16 in OVCAR3 cells activates the PI3K/Akt pathway (Comamala et al., 2011). The authors also reported that MUC16 knockdown in these cells decreased FOXO3a nuclear localization. FOXO3a function is controlled in part by activation of the Akt pathway. Akt phosphorylates FOXO3a, resulting in binding of FOXO3a to 14-3-3 proteins and retention of FOXO3a in the cytoplasm. In contrast, dephosphorylation of FOXO3a induces its nuclear localization where it transactivates gene expression (Nemoto et al., 2002). FOXO3a modulates the expression of several genes that regulate the cellular response to stress at the G2-M checkpoint. The growth arrest and DNA damage response gene Gadd54a is a target of FOXO3a that 
mediates part of FOXO3a's effects on DNA repair (Tran et al., 2002). Thus, preventing the nuclear localization of FOXO3a contributes to the apoptotic response to genotoxic drugs. These data suggest that MUC16 knockdown sensitizes tumor cells to genotoxic drugs by activating Akt which in turn prevents FOXO3a nuclear localization. The knockdown of MUC1 has also been reported to sensitize carcinoma cells to apoptosis induced by genotoxic agents (Yin et al., 2004; Ren et al., 2004).

EOC is a highly metastatic disease which primarily metastasizes to the serosal cavities while dissemination through the vasculature is unusual (Naora et al., 2005). During the progression to a metastatic phenotype, carcinoma cells undergo morphological changes, become motile and acquire the ability to migrate and invade to establish secondary tumors at distant sites. This epithelial to mesenchymal transition (EMT) is characterized by coordinated molecular and cellular changes including a reduction in cell-cell adhesion, the loss of apical-basolateral polarity, the loss of epithelial markers and the gain of mesenchymal markers (Vergara et al, 2010; Hugo et al, 2007). EMT is an important physiological process during embryogenesis and wound healing, but also a key step in cancer metastasis (Radisky, 2005). EMT is a necessary step towards metastatic tumor progression during detachment of tumor cells from the primary tumor site and attachment to metastatic sites. A key feature of EMT is the switch from E-cadherin expression at the cell surface to N-cadherin which promotes the interaction with stromal components (Cavallaro et al., 2004). EMT results in enhanced cell motility and invasion. MUC16 was recently shown to be an important regulator of EMT in OC cells (Comamala et al., 2011). Using a MUC16 knockdown OC cell model, the authors showed that downregulation of MUC16 cell surface expression prevents homotypic cell aggregation, enhances disruption of cell-cell junctions and increases cell motility and invasiveness. These effects were associated with the loss of epithelial markers such as E-cadherin and cytokeratin-18 and gain of mesenchymal markers such as N-cadherin and vimentin in knockdown cells. These data suggest that MUC16 is involved in the metastatic process. As mentioned previously, MUC16 knockdown induces an intracellular relocalization of E-cadherin. It is possible that the binding of MUC16 to Ecadherin complexes results in the surface localization of E-cadherin, which mediates cell contact and suppression of cell migration. Conversely, in the absence of MUC16, E-cadherin relocalizes in the cytoplasm, which abolishes its ability to promote cell contact formation. The cytoplasmic domain of E-cadherin binds to $\beta$-catenin, which forms complexes with acatenin (Ozawa et al, 1990), actin (Adams et al, 1996), p120 (Staddon et al, 1995), EGFR (Hoschuetzky et al, 1994), and other proteins. It is possible that by forming a complex with E-cadherin and/or $\beta$-catenin, MUC16 re-distributes EGFR and consequently modulates its signaling pathway. Although expression of MUC16 C-terminal domain in SKOV3 cells does not affect EGFR phosphorylation, MUC16 knockdown activates EGFR resulting in increased activation of Akt, ERK1/2 and MMP-2 and MMP-9 (Comamala et al., 2011). Activation of the MAPK-ERK pathway has been shown to upregulate MMP-9 and to enhance cell migration (Suyama et al, 2002). Akt activation has been associated with induction of EMT in carcinoma cells (Grille et al, 2003; Yan et al, 2009). In summary, the early steps in ovarian tumor metastasis involve shedding of the primary tumor through alterations of cell adhesive properties into ascites to form free floating cells or multicellular aggregates. Tumor cells from the primary site express MUC16, display a more epithelial phenotype and express Ecadherin. Shedding from the primary tumor site involves the loss of MUC16 and E-cadherin expression and the gain of mesenchymal markers leading to increased motility and loss of 
adhesive properties. Following this EMT, floating tumor cells revert to an epithelial phenotype and express MUC16 leading to adhesion to mesothelial cells via MUC16/mesothelin interaction and the formation of tumor implants in the peritoneal cavity.

MUC16 has been shown to alter tumorigenicity and metastasis of EOC cells (Thériault et al., 2011). MUC16 knockdown inhibited cell growth in soft agar and abolished the formation of subcutaneous tumor nodule. Conversely, the MUC16 C-terminal domain appears to be sufficient to enhance in vitro and in vivo tumorigenicity, and promote dissemination of tumor cells throughout the peritoneal cavity of SCID mice. Importantly, deletion of MUC16 cytoplasmic tail completely abolished these effects. Although the mechanism by which MUC16 affects tumorigenicity and metastasis is unknown, this study suggests that MUC16 plays a critical role in the progression of EOC.

Although MUC16's functions are beginning to be elucidated in EOC cells, the normal function of MUC16 is for the most part unknown. As mentioned previously, it is expressed by various tissues, notably the conjonctiva and the lachrymal glands, were it can play a protective role against bacterial infection. Its expression in fallopian tube and endometrium suggests a role in reproduction. However, knockout mice have been shown to display a normal phenotype by 1 year of age demonstrating that MUC16 is not required for mouse development and reproduction (Cheon et al., 2009). Consistent with these data, MUC1 null mice have normal fertility and development (Spicer et al., 1995). One explanation that has been evoked for the lack of phenotype for MUC16 and MUC1 knockout mice is that functional redundancy can compensate for the loss of other mucins.

\section{Conclusions and future directions}

Since its discovery in the late 1970s, MUC16 glycoprotein has been recognized as a useful clinical biomarker in advance diseases. However, accumulating evidence suggests that MUC16 is more than a biomarker for disease progression; MUC16 contributes to the pathogenesis and progression of EOC. MUC16 appears to regulate cell survival, cell motility, invasiveness and tumorigenicity in EOC cells. These phenotypic effects are also shared by other membrane-bounded mucins such as MUC1 and MUC4. However, the underlying mechanisms responsible for the biological functions are likely to differ between mucins because of their structural differences, notably in their cytoplasmic tail. Although progress has been made regarding the role of MUC16 in tumor progression, the signaling pathways activated by its cytoplasmic tail are mostly unknown. The functional role of MUC16/ $\beta$-catenin and MUC16/E-cadherin interactions is not known. Further studies are needed to understand the contribution of these interactions in tumor progression. Identifying the signaling molecules activated by MUC16 and elucidating their contribution to EOC progression will be critical in the near future as MUC16 may represent a target for EOC treatment.

\section{References}

Adams CL, Nelson WJ, Smith SJ. Quantitative analysis of cadherin-catenin-actin reorganization during development of cell-cell adhesion. J Cell Biol 1996;135:18991911. 
Aletti GD, Dowdy SC, Podratz KC, Cliby WA. Relationship among surgical complexity, short-term morbidity, and overall survival in primary surgery for advanced ovarian cancer. Am J Obstet Gynecol. 2007;197:676 e1-7.

Argueso P, Spurr-Michaud S, Russo CL, Tisdale A, Gipson IK. MUC16 mucin is expressed by the human ocular surface epithelia and carries the H185 carbohydrate epitope. Invest Ophthalmol Vis Sci 2003;44:2487-2495.

Auersperg N, Wong AS, Choi KC, Kang SK, Leung PC. Ovarian surface epithelium: biology, endocrinology, and pathology. Endocr Rev 2001;22:255-288.

Badgwell D, Bast RC Jr. Early detection of ovarian cancer. Dis Markers 2007;23:397-410.

Bafna S, Kaur S, Batra SK. Membrane-bound mucins: the mechanistic basis for alterations in the growth and survival of cancer cells. Oncogene 2010;29:2893-2904.

Bast RC Jr, Badgwell D, Lu Z, Marquez R, Rosen D, Liu J, Baggerly KA, Atkinson EN, Skates S, Zhang Z, Lokshin A, Menon U, Jacobs I, Lu K. New tumor markers: CA125 and beyond. Int J Gynecol Cancer 2005;15(suppl 3):274-281.

Bast RC Jr, Feeney M, Lazarus H, Nadler LM, Colvin RB, Knapp RC. Reactivity of a monoclonal antibody with human ovarian carcinoma. J Clin Invest 1981;68:13311337.

Bast RC Jr, Hennessy B, Mills GB. The biology of ovarian cancer: new opportunities for translation. Nat Rev Cancer 2009;9:415-428.

Bast RC Jr, Klug TL, St John E, Jenison E, Niloff JM, Lazarus H, Berkowitz RS, Leavitt T, Griffiths CT, Parker L, Zurawski VR Jr, Knapp RC. A radioimmunoassay using a monoclonal antibody to monitor the course of epithelial ovarian cancer. $\mathrm{N}$ Eng J Med 1983;309:883-887.

Belisle JA, Gubbels JA, Raphael CA, Migneault M, Rancourt C, Connor JP, Patankar MS. Peritoneal natural killer cells from epithelial ovarian cancer patients show an altered phenotype and bind to the tumour marker MUC16 (CA125). Immunology 2007;122:418-429.

Belisle JA, Horibata S, Jennifer GA, Petrie S, Kapur A, André S, Gabius HJ, Rancourt C, Connor J, Paulson JC, Patankar MS. Identification of Siglec-9 as the receptor for MUC16 on human NK cells, B cells, and monocytes. Mol Cancer 2010;9:118.

Blalock TD, Spurr-Michaud SJ, Tisdale AS, Heimer SR, Gilmore MS, Ramesh V, Gipson IK. Functions of MUC16 in corneal epithelial cells. Invest Ophthalmol Vis Sci 2007;48:4509-18.

Boivin M, Lane D, Piché A, Rancourt C. CA125 (MUC16) tumor antigen selectively modulates the sensitivity of ovarian cancer cells to genotoxic drug-induced apoptosis. Gynecol Oncol 2009 115:407-413, .

Breitenecker G, Neunteufel W, Bieglmayer C, Kolbl H, Schieder K. Comparison between tissue and serum content of CA 125, CA 19-9, and carcinoembryonic antigen in ovarian tumors. Int J Gynecol Pathol 1989;8:97-102.

Canney PA, Moore M, Wilkinson PM, James RD. Ovarian cancer antigen CA125: a prospective clinical assessment of its role as a tumour marker. Br J Cancer 1984;50:765-769.

Carraway KL 3rd, Funes M, Workman HC, Sweeney C. Contribution of membrane mucins to tumor progression through modulation of cellular growth signaling pathways. Curr Top Dev Biol 2007;78:1-22. 
Cavallaro U, Christofori G. Cell adhesion and signalling by cadherins and Ig-CAMs in cancer. Nat Rev Cancer 2004;4:118-132.

Chang K, Pastan I. Molecular cloning of mesothelin, a differentiation antigen present on mesothelium, mesotheliomas, and ovarian cancers. Proc Natl Acad Sci USA 1996;93:136-140.

Cheon DJ, Wang Y, Deng JM, Lu Z, Xiao L, Chen CM, Bast RC, Behringer RR. CA125/MUC16 is dispensable for mouse development and reproduction. PlosOne 2009;4:e4675.

Colombo N, Van Gorp T, Parma G, Amant F, Gatta G, Sessa C, Vergote I. Ovarian cancer. Crit Rev Oncol Hematol 2006;60:159-179.

Comamala M, Pinard M, Thériault C, Matte I, Albert A, Boivin M, Beaudin J, Piché A, Rancourt C. Downregulation of cell surface CA125/MUC16 induces epithelial-tomesenchymal transition and restores EGFR signaling in NIH:OVCAR3 ovarian carcinoma cells. Br J Cancer 2011;104:989-999.

Crum CP, Drapkin R, Kindelberger D, Medeiros F, Miron A, Lee Y. Lessons from BRCA: the tubal fimbria emerges as an origin for pelvic serous cancer. Clin Med Res 2007;5:3544.

Crum CP, Drapkin R, Miron A, Ince TA, Muto M, Kindelberger DW, Lee Y. The distal fallopian tube: a new model for pelvic serous carcinogenesis. Curr Opin Obstet Gynecol 2007;19:3-9.

Davies JR, Kirkham S, Svitacheva N, Thornton DJ, Carlstedt I. MUC16 is produced in tracheal surface epithelium and submucosal glands and is present in secretions from normal human airway and cultured bronchial epithelial cells. Int J Biochem Cell Biol 2007;39:1943-1954.

Davis HM, Zurawski VR Jr, Bast RC Jr, Klug TL. Characterization of the CA 125 antigen associated with human epithelial ovarian carcinomas. Cancer Res 1986;46:61436148.

de la Cuesta R, Maestro ML, Solana J, Vidart JA, Escudero M, Iglesias E, Valor R.. Tissue quantification of CA 125 in epithelial ovarian cancer. Int J Biol Markers 1999;14:106-114.

Dharma Rao T, Park KJ, Smith-Jones P, Iasonos A, Linkov I, Soslow RA, Spriggs DR. Novel Monoclonal Antibodies Against the Proximal (Carboxy-Terminal) Portions of MUC16. Appl Immunohistochem Mol Morphol 2010;18:462-472.

Dubeau L. The cell of origin of ovarian epithelial tumours. Lancet Oncol 2008;9:11911197.

Duraisamy S, Ramasamy S, Kharbanda S, Kufe D. Distinct evolution of the human carcinoma-associated transmembrane mucins, MUC1, MUC4 and MUC16. Gene 2006;373:28-34.

Fendrick JL, Konishi I, Geary SM, Parmley TH, Quirk JG Jr, O'Brien TJ. CA125 phosphorylation is associated with its secretion from the WISH human amnion cell line. Tumour Biol 1997;18:278-289.

Goff BA, Mandel L, Muntz HG, Melancon CH. Ovarian carcinoma diagnosis. Cancer 2000;89:2068-2075.

Grille SJ, Bellacosa A, Upson J, Klein-Szanto AJ, van Roy F, Lee-Kwon W, Donowitz M, Tsichlis PN, Larue L. The protein kinase Akt induces epithelial-mesenchymal 
transition and promotes enhanced motility and invasiveness of squamous cell carcinoma lines. Cancer Res 2003;63:2172-2178.

Gronowitz E, Pitkanen S, Kjellmer I, Heikinheimo M, Strandvik B. Association between serum oncofetal antigens CA 19-9 and CA 125 and clinical status in patients with cystic fibrosis. Acta Paediatr 2003;92:1267-1271.

Gubbels JA, Belisle J, Onda M, Rancourt C, Migneault M, Ho M, Bera TK, Connor J, Sathyanarayana BK, Lee B, Pastan I, Patankar MS. Mesothelin-MUC16 binding is a high affinity, N-glycan dependent interaction that facilitates peritoneal metastasis of ovarian tumors. Mol Cancer 2006;5:50.

Gubbels JA, Felder M, Horibata S, Belisle JA, Kapur A, Holden H, Petrie S, Migneault M, Rancourt C, Connor JP, Patankar MS. MUC16 provides immune protection by inhibiting synapse formation between NK and ovarian tumor cells. Mol Cancer 2010;9:11.

Hattrup CL, Gendler SJ. Structure and function of cell surface (tethered) mucins. Annu Rev Physiol 2008;70:431-457.

Herzog TJ. Recurrent ovarian cancer: how important is it to treat to disease progression? Clin Cancer Res 2004;10:7439-7449.

Hogdall EV, Christensen L, Kjaer SK, Blaakaer J, Kjaerbye-Thygesen A, Gayther S, Jacobs IJ, Hogdall CK. CA125 expression pattern, prognosis and correlation with serum CA125 in ovarian tumor patients from the danish "MALOVA" ovarian cancer study. Gynecol Oncol 2007;104:508-515.

Hoschuetzky H, Aberle H, Kemler R. $\beta$-catenin mediates the interaction of the cadherincatenin complex with epidermal growth factor receptor. J Cell Biol 1994;127:13751380.

Huang L, Chen D, Liu D, Yin L, Kharbanda S, Kufe D. MUC1 oncoprotein blocks glycogen synthase kinase $3 \beta$-mediated phosphorylation and degradation of $\beta$-catenin. Cancer Res 2005;65:10413-10422.

Hugo H, Ackland ML, Blick T, Lawrence MG, Clements JA, Williams ED, Thompson EW. Epithelial-mesenchymal and mesenchymal-epithelial transitions in carcinoma progression. J Cell Physiol 2007;213:374-383.

Jäger K, Wu G, Sel S, Garreis F, Bräuer L, Paulsen FP. MUC16 in the lacrimal apparatus. Histochem Cell Biol 2007;127:433-438.

Jemal A, Siegel R, Xu J, Ward E. Cancer Statistics 2010. CA Cancer J Clin 2010;60:277-300.

Jepson S, Komatsu M, Haq B, Arango ME, Huang D, Carraway CA, Carraway KL. Muc4/sialomucin complex, the intramembrane erbB2 ligand, induces specific phosphorylation of ErbB2 and enhances expression of p27(kip), but does not activate mitogen-activated kinase or protein kinaseB/Akt pathways. Oncogene 2002;21:7524-7532.

Kabawat SE, Bast RC Jr, Bhan AK, Welch WR, Knapp RC, Colvin RB. Tissue distribution of a coelomic epithelium-related antigen recognized by the monoclonal antibody OC125. Int J Gynecol Pathol 1983;2:275-285.

Kaneko O, Gong L, Zhang J, Hansen JK, Hassan R, Lee B, Ho M. A binding domain on mesothelin for CA125/MUC16. J Biol Chem 2009;284:3739-3749. 
Karlan B, Amin W, Casper SE, Littlefield BA. Hormonal regulation of CA125 tumor marker expression in human ovarian carcinoma cells: inhibition by glucocorticoids. Cancer Res 1988;48:3502-3506.

Kindelberger DW, Lee Y, Miron A, Hirsch MS, Feltmate C, Medeiros F, Callahan MJ, Garner EO, Gordon RW, Birch C, Berkowitz RS, Muto MG, Crum CP. Intraepithelial carcinoma of the fimbria and pelvic serous carcinoma: evidence for a causal relationship. Am J Surg Pathol 2007;31:161-9.

Konishi I, Fendrick JL, Parmley TH, Quirk JG Jr, O'Brien TJ. Epidermal growth factor enhances secretion of the ovarian tumor-associated cancer antigen CA125 from the human amnion WISH cell line. J Soc Gynecol Invest 1994;1:89-96.

Konstantinopoulos PA, Spentzos D, Cannistra SA. Gene-expression profiling in epithelial ovarian cancer. Nat Clin Pract Oncol 2008;5:577-587.

Krivak TC, Tian C, Rose GS, Armstrong DK, Maxwell GL. A Gynecologic Oncology Group Study of serum CA-125 levels in patients with stage III optimally debulked ovarian cancer treated with intraperitoneal compared to intravenous chemotherapy: an analysis of patients enrolled in GOG 172. Gynecol Oncol 2009;115:81-85.

Kui WN, Easton RL, Panico M, Sutton-Smith M, Morrison JC, Lattanzio FA, Morris HR, Clark GF, Dell A, Patankar MS. Characterization of the oligosaccharides associated with the human ovarian tumor marker CA125. J Biol Chem 2003;278:28619-28634.

Kurman RJ, Shih IM. The origin and pathogenesis of epithelial ovarian cancer: a proposed unifying theory. Am J Surg Pathol 2010;34:433-443.

Landen CN Jr, Birrer MJ, Sood AK. Early events in the pathogenesis of epithelial ovarian cancer. J Clin Oncol 2008;26:995-1005.

Li Y, Bharti A, Chen D, Gong J, Kufe D. Interaction of glycogen synthase kinase $3 \beta$ with the DF3/MUC1 carcinoma-associated antigen and $\beta$-catenin. Mol Cell Biol 1998;18:7216-7224.

Li Y, Liu D, Chen D, Kharbanda S, Kufe D. Human DF3/MUC1 carcinoma-associated protein functions as an oncogene. Oncogene 2003;22:6107-6110.

Li Y, Ren J, Yu W, Li Q, Kuwahara H, Yin L Carraway KL 3rd, Kufe D. The epidermal growth factor receptor regulates interaction of the human DF3/MUC1 carcinoma antigen with c-Src and beta-catenin. J Biol Chem 2001;276:35239-35242.

Lloyd KO, Yin BW, Kudryashov V. Isolation and characterization of ovarian cancer antigen CA 125 using a new monoclonal antibody (VK-8): identification as a mucin-type molecule. Int J Cancer 1997;71:842-850.

Lloyd KO, Yin BW. Synthesis and secretion of the ovarian cancer antigen CA 125 by the human cancer cell line NIH:OVCAR-3. Tumour Biol 2001;22:77-82.

Lu KH, Patterson AP, Wang L, Marquez RT, Atkinson EN, Baggerly KA, Ramoth LR, Rosen DG, Liu J, Hellstrom I, Smith D, Hartmann L, Fishman D, Berchuck A, Schmandt R, Whitaker R, Gershenson DM, Mills GB, Bast RC Jr. Selection of potential markers for epithelial ovarian cancer with gene expression arrays and recursive descent partition analysis. Clin Cancer Res 2004;10:3291-3300.

Mano MS, Rosa DD, Azambuja E, Ismael G, Braga S, D'Hondt V, Piccart M, Awada A. Current management of ovarian carcinosarcoma. Int J Gynecol Cancer 2007;17:31624. 
McGuire WP, Hoskins WJ, Brady MF, Kucera PR, Partridge EE, Look KY, Clarke-Pearson DL, Davidson M. Cyclophosphamide and cisplatin versus paclitaxel and cisplatin: a phase III randomized trial in patients with suboptimal stage III/IV ovarian cancer (from the Gynecologic Oncology Group). Semin Oncol. 1996;5 (Suppl 12):40-7.

Naora H, Montell DJ. Ovarian cancer metastasis: integrating insights from disparate model organisms. Nat Rev Cancer 2005;5:355-366.

Nap M. Immunohistochemistry of CA125. Unusual expression in normal tissues, distribution in the human fetus and questions around its application in diagnostic pathology. Int J Biol Markers 1998;13:210-215.

Nemoto S, Finkel T. Redox Regulation of Forkhead Proteins Through a p66shc-Dependent Signaling Pathway. Science 2002;295:2450-2452.

Nustad K, Lebedin Y, Lloyd KO, Shigemasa K, de Bruijn HW, Jansson B, Nilsson O, Olsen $\mathrm{KH}, \mathrm{O}^{\prime}$ Brien TJ. Epitopes on CA125 from cervical mucus and ascites fluid and characterization of six new antibodies. Third report from the ISOBM TD-1 workshop. Tumour Biol 2002;23:303-314.

O'Brien TJ, Beard JB, Underwood LJ, Dennis RA, Santin AD, York L. The Ca125 gene: an extracellular superstructure dominated by repeat sequences. Tumour Biol 2001;22:348-466.

O'Brien TJ, Beard JB, Underwood LJ, Shigemasa K. The CA 125 gene: a new discovered extension of the glycosylated N-terminal domain doubles the size of this extracellular superstructure. Tumour Biol 2002;23:154-169.

Ouellet V, Guyot MC, Le Page C, Filali-Mouhim A, Lussier C, Tonin PN, Provencher DM, Mes-Masson AM. Tissue array analysis of expression microarray candidates identifies markers associated with tumor grade and outcome in serous epithelial ovarian cancer. Int J Cancer 2006;119:599-607.

Ouellet V, Ling TH, Normandin K, Madore J, Lussier C, Barrès V, Bachvarov D, Rancourt C, Tonin PN, Provencher DM, Mes-Masson AM. Immunohistochemical profiling of benign, low malignant potential and low grade serous epithelial ovarian tumors. BMC Cancer 2008;8:346.

Ouellet V, Provencher DM, Maugard CM, Le Page C, Ren F, Lussier C, Novak J, Ge B, Hudson TJ, Tonin PN, Mes-Masson AM. Discrimination between serous low malignant potential and invasive epithelial ovarian tumors using molecular profiling. Oncogene 2005;24:4672-4687.

Ozawa M, Ringwald M, Kemler R. Uvomorulin-catenin complex formation is regulated by a specific domain in the cytoplasmic region of the cell adhesion molecule. Proc Natl Acad Sci USA 1990;87:4246-4250.

Ozols RF, Bookman MA, Connolly DC, Daly MB, Godwin AK, Schilder RJ, Xu X, Hamilton TC. Focus on epithelial ovarian cancer. Cancer Cell 2004;5:19-24.

Patankar MS, Jing Y, Morrison JC, Belisle JA, Lattanzio FA, Deng Y, Wong NK, Morris HR, Dell A, Clark GF. Potent suppression of natural killer cell response mediated by the ovarian tumor marker CA125. Gynecol Oncol 2005;99:704-713.

Perillo NL, Marcus ME, Baum LG. Galectins : versatile modulators of cell adhesion, cell proliferation, and cell death. J Mol Med 1998;76:402-412.

Pochampalli MR, el Bejjani RM, Schroeder JA. MUC1 is novel regulator of ErbB1 receptor trafficking. Oncogene 2007;26:1693-1701. 
Radisky DC. Epithelial-mesenchymal transition. J Cell Sci 2005;118:4325-4326.

Raina D, Kharbanda S, Kufe D. The MUC1 oncoprotein activates the anti-apoptotic phosphoinositide 3-kinase/Akt and Bcl-XL pathways in rat 3Y1 fibroblast. J Biol Chem 2004;279:20607-20612.

Ren J, Agata N, Chen D, Li Y, Yu WH, Huang L, Raina D, Chen W, Kharbanda S, Kufe D. Human MUC1 carcinoma-associated protein confers resistance to genotoxic anticancer agents. Cancer Cell 2004;5:163:175.

Ren J, Raina D, Chen W, Li G, Huang L, Kufe D. MUC1 oncoprotein functions in activation of fibroblast growth factor receptor signaling. Mol Cancer Res 2006;4:873-883.

Rosen DG, Wang L, Atkinson JN, Yu Y, Lu KH, Diamandis EP, Hellstrom I, Mok SC, Liu J, Bast RC Jr. Potential markers that complement expression of CA125 in epithelial ovarian cancer. Gynecol Oncol 2005;99:267-77.

Rump A, Morikawa Y, Tanaka M, Minami S, Umesaki N, Takeuchi M, Miyajima A. Binding of ovarian cancer antigen CA125/MUC16 to mesothelin mediates cell adhesion. J Biol Chem 2004;279:9190-9198.

Rustin GJ, Nelstrop AE, Tuxen MK, Lambert HE. Defining progression of ovarian carcinoma during follow-up according to CA 125: a North Thames Ovary Group Study. Ann Oncol 1996;7:361-364.

Schroeder JA, Thompson MC, Gardner MM, Gendler SJ. Transgenic MUC1 interacts with epidermal growth factor receptor and correlates with mitogen-activated protein kinase activation in the mouse mammary gland. J Biol Chem 2001;276:1305713064.

Schwartz DR, Kardia SL, Shedden KA, Kuick R, Michailidis G, Taylor JM, Misek DE, Wu R, Zhai Y, Darrah DM, Reed H, Ellenson LH, Giordano TJ, Fearon ER, Hanash SM, Cho KR. Gene expression in ovarian cancer reflects both morphology and biological behavior, distinguishing clear cell from other poor-prognosis ovarian carcinomas. Cancer Res 2002;62:4722-4729.

Seelenmeyer C, Wegehingel S, Lechner J, Nickel W. The cancer antigen CA125 represents a novel counter receptor for galectin-1. J Cell Sci 2003;116:1305-1318.

Singh PK, Hollingsworth MA. Cell surface-associated mucins in signal transduction. Trends Cell Biol 2006;16:467-476.

Soslow RA. Histologic subtypes of ovarian carcinoma: an overview. Int J Gynecol Pathol 2008;27:161-174.

Spicer AP, Rowse GJ, Lidner TK, Gendler SJ. Delayed mammary tumor progression in Muc1 null mice. J Biol Chem 1995;270:30093-30101.

Staddon JM, Smales C, Schulze C, Esch FS, Rubin LL. p120, a p120-related protein (p100), and the cadherin/catenin complex. J Cell Biol 1995;130:369-381.

Suyama K, Shapiro I, Guttman M, Hazan RB. A signaling pathway leading to metastasis is controlled by N-cadherin and the FGF receptor. Cancer Cell 2002;2:301-314.

Thériault C, Pinard M, Comamala M, Migneault M, Beaudin J, Matte I, Boivin M, Piché A, Rancourt C. MUC16 (CA125) regulates epithelial ovarian cancer cell growth, tumorigenesis and metastasis. Gynecol Oncol 2011;121:434-443. 
Tran H, Brunet A, Grenier JM, Datta SR, Fornace AJ Jr, DiStefano PS, Chiang LW, Greenberg ME. DNA repair pathway stimulated by the forkhead transcription factor FOXO3a through the Gadd45 protein. Science 2002;296:530-534.

Van Altena AM, Kolwijck E, Spanjer MJ, Hendriks JC, Massuger LF, de Hullu JA. CA125 nadir concentration is an independent predictor of tumor recurrence in patients with ovarian cancer: a population-based study. Gynecol Oncol 2010;119:265-269.

Vergara D, Merlot B, Lucot JP, Collinet P, Vinatier D, Fournier I, Salzet M. Epithelialmesenchymal transition in ovarian cancer. Cancer Lett 2010;291:59-66.

Vergote IB, Bormer OP, Abeler VM. Evaluation of serum CA 125 levels in the monitoring of ovarian cancer. Am J Obstet Gynecol 1987;157:88-92.

Wen Y, Caffrey T`C, Wheelock MJ, Johnson KR, Hollingsworth MA. Nuclear association of the cytoplasmic tail of MUC1 and $\beta$-catenin. J Biol Chem 2003;278:3802938039.

Xiaofang Y, Yue Z, Xialian X, Zhibin Y. Serum tumour markers in patients with chronic kidney disease. Scand J Clin Lab Invest 2007;67:661-667.

Yamamoto M, Bharti A, Li Y, Kufe D. Interaction of the DF3/MUC1 breast carcinomaassociated antigen and $\beta$-catenin in cell adhesion. J Biol Chem 1997;272:1249212494.

Yan W, Fu Y, Tian D, Liao J, Liu M, Wang B, Xia L, Zhu Q, Luo M. PI3 kinase/Akt signaling mediates epithelial-mesenchymal transition in hypoxic hepatocellular carcinoma cells. Biochem Biophys Res Commun 2009;382:631-636.

Yin BW, Dnistrian A, Lloyd KO, Ovarian cancer antigen CA125 is encoded by the MUC16 mucin gene. Int J Cancer 2002;98:737-740.

Yin BW, Lloyd KO. Molecular cloning of the CA125 ovarian cancer antigen: identification as a new mucin, MUC16. J Biol Chem 2001;276:27371-27375.

Yin L, Huang L, Kufe D. MUC1 oncoprotein activates the FOXO3a transcription factor in a survival response to oxidative stress. J Biol Chem 2004;279:45721-45727.

Zorn KK, Tian C, McGuire WP, Hoskins WJ, Markman M, Muggia FM, Rose PG, Ozols RF, Spriggs D, Armstrong DK. The prognostic value of pretreatment CA 125 in patients with advanced ovarian carcinoma: a Gynecologic Oncology Group Study. Cancer 2009;115:1028-1035. 


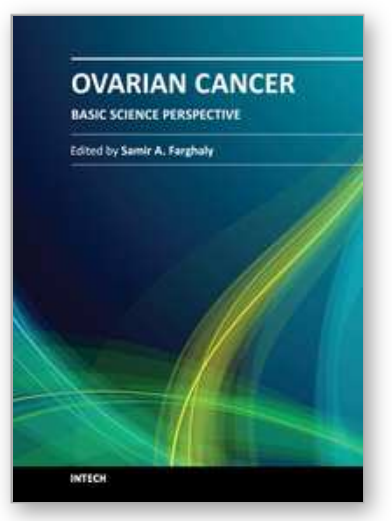

\author{
Ovarian Cancer - Basic Science Perspective \\ Edited by Dr. Samir Farghaly
}

ISBN 978-953-307-812-0

Hard cover, 406 pages

Publisher InTech

Published online 17, February, 2012

Published in print edition February, 2012

Worldwide, Ovarian carcinoma continues to be responsible for more deaths than all other gynecologic malignancies combined. International leaders in the field address the critical biologic and basic science issues relevant to the disease. The book details the molecular biological aspects of ovarian cancer. It provides molecular biology techniques of understanding this cancer. The techniques are designed to determine tumor genetics, expression, and protein function, and to elucidate the genetic mechanisms by which gene and immunotherapies may be perfected. It provides an analysis of current research into aspects of malignant transformation, growth control, and metastasis. A comprehensive spectrum of topics is covered providing up to date information on scientific discoveries and management considerations.

\title{
How to reference
}

In order to correctly reference this scholarly work, feel free to copy and paste the following:

Claudine Rancourt, Isabelle Matte, Denis Lane and Alain Piché (2012). The Role of MUC16 Mucin (CA125) in the Pathogenesis of Ovarian Cancer, Ovarian Cancer - Basic Science Perspective, Dr. Samir Farghaly (Ed.), ISBN: 978-953-307-812-0, InTech, Available from: http://www.intechopen.com/books/ovarian-cancer-basicscience-perspective/the-implications-of-muc16-ca125-mucin-in-the-pathogenesis-of-ovarian-cancer

\section{INTECH}

open science | open minds

\section{InTech Europe}

University Campus STeP Ri

Slavka Krautzeka 83/A

51000 Rijeka, Croatia

Phone: +385 (51) 770447

Fax: +385 (51) 686166

www.intechopen.com

\section{InTech China}

Unit 405, Office Block, Hotel Equatorial Shanghai

No.65, Yan An Road (West), Shanghai, 200040, China 中国上海市延安西路65号上海国际贵都大饭店办公楼 405 单元

Phone: +86-21-62489820

Fax: $+86-21-62489821$ 
(C) 2012 The Author(s). Licensee IntechOpen. This is an open access article distributed under the terms of the Creative Commons Attribution 3.0 License, which permits unrestricted use, distribution, and reproduction in any medium, provided the original work is properly cited. 